\title{
Determinants of Share Price Movement on Government-linked Companies in Malaysia
}

\author{
Mohd Naim Mohd Yussof ${ }^{1}$, Mazurina Mohd Ali ${ }^{2, *}$, Erlane K Ghani \\ ${ }^{1}$ Lembaga Hasil Dalam Negeri Malaysia, Jabatan Audit Dalam, Menara Hasil, Aras 7, Persiaran Rimba Permai, Cyber 8, 63000 , \\ Cyberjaya, Selangor, Malaysia \\ ${ }^{2}$ Faculty of Accountancy, Universiti Teknologi MARA Selangor, Kampus Puncak Alam, 42300 Bandar Puncak Alam, \\ Selangor, Malaysia \\ *Corresponding Author: mazurina@uitm.edu.my
}

Received August 7, 2020; Revised October 25, 2020; Accepted December 30, 2020

\section{Cite This Paper in the following Citation Styles}

(a): [1] Mohd Naim Mohd Yussof, Mazurina Mohd Ali, Erlane K Ghani, "Determinants of Share Price Movement on Government-linked Companies in Malaysia," Universal Journal of Accounting and Finance, Vol. 8, No. 4, pp. 161 - 169, 2020. DOI: 10.13189/ujaf.2020.080409.

(b): Mohd Naim Mohd Yussof, Mazurina Mohd Ali, Erlane K Ghani (2020). Determinants of Share Price Movement on Government-linked Companies in Malaysia. Universal Journal of Accounting and Finance, 8(4), 161 - 169. DOI: 10.13189/ujaf.2020.080409.

Copyright $C 2020$ by authors, all rights reserved. Authors agree that this article remains permanently open access under the terms of the Creative Commons Attribution License 4.0 International License

\begin{abstract}
The role of government-linked companies (GLCs) in Malaysia is vital for the growth of the economy in Malaysia. Nonetheless, the perception from the public at large towards GLCs in Malaysia was unpleasant because of the performance not as it should be as GLCs. Using 17 GLCs listed on the Bursa Malaysia, this study aims to investigate the factors that determine the share prices for the GLCs in Malaysia over the period from 2013 until 2017. The influence of the independent variables, namely return on asset, return on equity, dividend per share, price-earnings ratio, current ratio and acid test ratio on the share prices were tested using multiple regression analysis. The result of this study shows that those variables account for $69.6 \%$ of GLCs share price movements. Additionally, dividend per share, price-earnings ratio and acid test ratio are significantly positively related to share prices. These findings imply that for managers to create value for their shareholders, they should increase the dividend paid to shareholders, improve the company's earnings and have more liquid assets.
\end{abstract}

Keywords Government-linked Companies, GLCs, Share Price, Performance, Malaysia

\section{Introduction}

The share price movement is the highest priority for the shareholders to consider when they decide on their investment. The share price is very volatile because it fluctuates. The management concerns about the share price movement since the price shows the credibility and capability of their management. The movement of share price also reflects the company's performance in the eyes of investors. The motivation of this study is to examine the determinants of companies' performance, i.e., the share price movement for government-linked companies (GLCs). The topmost influential factors found in most of the past studies include profitability and liquidity, by which are the financial factors. Udding [1] has suggested that book value per share, earnings per share, dividend and net asset value and, gross domestic product, among others, are elements that affect share prices. These factors are primarily because of the essence of the financial viewpoint, which consists of the notion of capital management composition, either equity or debt. As the share prices gauge on whether or not investors should invest, the quality of equity funds exclusively relies on share prices. The equity market is essential to financial managers as a result of its capability to grant returns to investors with the least risks and present access to capital for companies [2]. The fact that the knowledge of the factors that determine the changes in share price conveys valuable information to management, it is also promising to enhance the firm's value [3].

The rising economic growth and promoting capital formation are part of the contribution of the share market 
towards the economy. To date, there have been continuous arguments about the effectiveness of government-linked companies in which the majority shareholdings by the government has either a positive or negative effect on the companies' performance. The proponents, who assert that GLCs perform better than non-GLCs have recognized few conditions. For example, the efficient structure of corporate governance, the impressive monitoring mechanism, and preference in granting government concessions and contracts, as aspects that add to more excellent performance. The opponents, however, argued that GLCs would suffer from the government's connexion due to government's appointment and appropriation of unqualified and incompetent managers and directors and also non-business intervention [4]. They insisted that non-GLCs should perform better than GLCs because non-GLCs are free from the influence or control by the government [4]. These arguments have led the GLCs to emphasis on business considerations to maximize shareholders' value and profits.

In Malaysia, a study by Isa and Lee [4] found that GLCs are underperforming as compared to non-GLCs. The performance is measured by financial structures, namely, return on asset, return on invested capital, return on equity, earnings per share and Tobin's $Q$ ratio. The underperforming of GLCs become a question to investors about whether the Government involvement in companies is considered detrimental to the GLCs performance [5]. Thus, this study aims to examine the determining factors of the share price performance of GLCs in Malaysia. Specifically, this study focuses on the following objectives: i) to investigate the effect of return on invested capital (i.e., return on asset and return on equity) on the share price performance of Malaysian GLCs; ii) to examine the effect of profitability (i.e., dividend per share and price-earnings ratio) on the share price performance of Malaysian GLCs and iii) to investigate the impact of liquidity (i.e., current ratio and acid test (quick) ratio) on the share price performance of Malaysian GLCs. The results of this study would benefit investors in evaluating the sufficient information required to make informed decisions on their investment.

The next section, Section 2, explains the literature review and hypotheses development. This is followed by Section 3 that presents and discusses the research design and method, while Section 4 presents and discusses the empirical model, tests, and findings of this study. The last section, Section 5, concludes this study.

\section{Literature Review and Hypotheses Development}

\subsection{Government Linked Companies in Malaysia}

In Malaysia, the role of government-linked companies (GLCs) is vital for the growth of the economy [6]. In 2004, the Malaysian government launched the Government Linked Companies Transformation Program intending to transform GLCs into high-performance entities. The aim is to enhance its role in the growth of the Malaysian economy [7]. GLCs are granted special assistance and focus by the government; therefore, the management should be more efficient, and the performance should be significantly enhanced [8]. GLCs should stress out to improve their sensitivity analysis, return on investment, return on sales, profit and sales growth, as well as engaging in customers' satisfaction, environment and community issues [9]. In other words, GLCs should focus on various aspects of financial and non-financial structures to bring about high intrinsic worth.

According to Mahbob [10], the GLCs have three central functions. First, based on research and development and intellectual asset development, GLCs may have to help create new wealth. Second, GLCs may enable Malaysians to access opportunities globally by enhancing national talents to manage major corporations of international standing. Third, GLCs must show concern about corporate social responsibility mostly related to pursuing environment care, poverty eradication, human capital, and improving economic imbalances. The Malaysian government, through its Federal Government-Linked Investment Companies (GLICs) have a control on the GLCs. As the investment arms of the government, GLICs set apart government funds and have ownership in GLCs. The Malaysian government also influences in term of the appointed members of the board of directors and senior management positions [6]. The former Prime Minister, Tun Dr Mahathir Mohamad, said that the GLCs and GLICs must give attention to generate strong institutions and establishing the necessary infrastructure to improve the country's growth [11].

\subsection{Efficient Capital Market Theory}

The efficient capital market theory suggests that, relative to all publicly available information, the price of traded securities perfectly reflect the securities' intrinsic values [12]. The market usually will react instantly to relevant information (i.e., share price), and it shows the capabilities of its current management. An efficient capital market is when an investor may increase his/her complete chances of speculative gain [12]. These chance can be done by obtaining public goods (i.e., information) about the companies and assessing that information wisely (whether to buy, hold or sell shares). The efficacy of the securities markets evaluated in terms of operational efficiency. Operational efficiency mentions the costs of issuing or transferring share price.

In an efficient capital market, all information about a company's share price is mirrored in its price, making the share price is the best available gauges of their value. The share price is also a signal for capital allocation. In relating the financial performance with the market performance, 
market performance measured by the financial performance of the companies. If the company's performing better, it will reflect on right economic measurement such as financial ratios.

\subsection{Return on Invested Capital and Share Price}

Return on invested capital shows how well a company is using its cash to generate returns. In this study, the return on invested capital is measured by the two financial indicators, namely, return on equity and return on asset towards share price. If the return on equity or return on asset has effects on share price, thus return on invested capital also have an impact on the share price. Naveed \& Ramzan [13] found an insignificant influence between dividend yield, return on assets and assets growth and share price. Besides, Uwuigbe, Olusegun \& Goodswill [14] examine the determinants of share prices in Nigeria. They found that the firms' financial performance has significant and positive relationships with the market value of shares.

Return on asset and return on equity affect performance measures because it acts as an indicator of the health of the companies. If the companies perform better (higher return on invested capital), thus it will give a return to the companies and the investor in term of the increased share price. It is suggested that companies that generate a stable return on invested capital over time possess a competitive advantage and well-valued.

Therefore, the first hypotheses are as follows:

H1a: There is a positive and significant relationship between return on asset and share price.

$\mathrm{H} 1 \mathrm{~b}$ : There is a positive and significant relationship between return on equity and share price.

\subsection{Profitability and Share Price}

In this study dividend per share and the price-earnings ratio is the sub-category for profitability measurement on the financial performance. Dividend per share and price-earnings will be used to examine the relationship with share price for market performance. A study by Enow $\&$ Brijlal [15] found that dividends per share, earnings per share and price-earnings ratio affects share price significantly. They aim to examine the contributing factor of share prices in South Africa. They found that earnings per share, dividend per share, and price-earnings ratio accounts for $57.8 \%$ of the movement of share prices. Also, they found that all the ratios affect share prices except dividend per share. From the results, it suggested that by increasing earnings per share and price-earnings, the shareholders' value will increase. In another study by Malhotra and Tandon [16], they found that the earnings per share, book value and price-earnings ratio accounts for $51.6 \%$ of the movements of the share price. Besides, Almumani [17] found that earnings per share, dividend per share, price-earnings ratio and book value are the primary determinant factor of share prices in Amman.

As a summary, results from previous research stated that dividend per share and price-earnings effect on the share price. Therefore, this study aims to investigate the influence of dividend per share and price-earnings on share price (market performance) on government-linked companies. Since, the market will respond immediately to relevant information, a high dividend per share and price-earnings will reflect a high share price return to the investors.

Therefore, the second hypotheses are as follows:

H2a: There is a positive and significant relationship between dividend per share and share price.

$\mathrm{H} 2 \mathrm{~b}$ : There is a positive and significant relationship between price-earnings ratios and share price.

\subsection{Liquidity and Share Price}

Research suggests that liquidity of a company indicates good financial performance and enhance the reliability of financial reporting as it determines the ability of a company to settle the debts within the stipulated times. Liquidity can be measured by the two financial indicators that are the current ratio and acid test (quick) ratio. Alves, Canadas \& Rodrigues [18] studied the effect of rules of governance on liquidity and share price. They used the bid-ask spread and turnover ratio as proxies for the information asymmetry. Their results showed that ownership structure influences the liquidity and share prices.

As a summary, previous research stated that liquidity in financial has a significant positive effect on share prices. Thus, if government-linked companies have better financial liquidity performance, it will contribute to better market performance. Liquidity ratios determine the skills and abilities of present management to meet the short-term liabilities with no unwelcome loss, especially in term of operational. Efficiency in operation will give a good indicator that the companies had performed well, then it will be reflected in the high return to the investor in term of the share price.

Therefore, the third hypotheses are as follows:

H3a: There is a positive and significant relationship between the current ratio and share price.

$\mathrm{H} 3 \mathrm{~b}$ : There is a positive and significant relationship between the acid test ratio and share price.

\section{Research Design and Method}

\subsection{Research Framework}

The fundamental purpose of this study is to examine the possible relationship between financial performance (independent variables) and the market performance (dependent variable) of Malaysian government-linked companies. Notably, three main variables used as proxies 
for financial performance, namely return on invested capital, profitability and liquidity. Return on asset and return on equity was used as measurements for return on invested capital; while dividend per share and price-earnings ratios as measurements for profitability. In contrast, liquidity ratio used current ratio and acid test (quick) ratio as the measurement.

The control variable is the firm size, as it also could influence the dependent variable. Figure 1 below shows the summary of all the tested variables and their connections with each other.

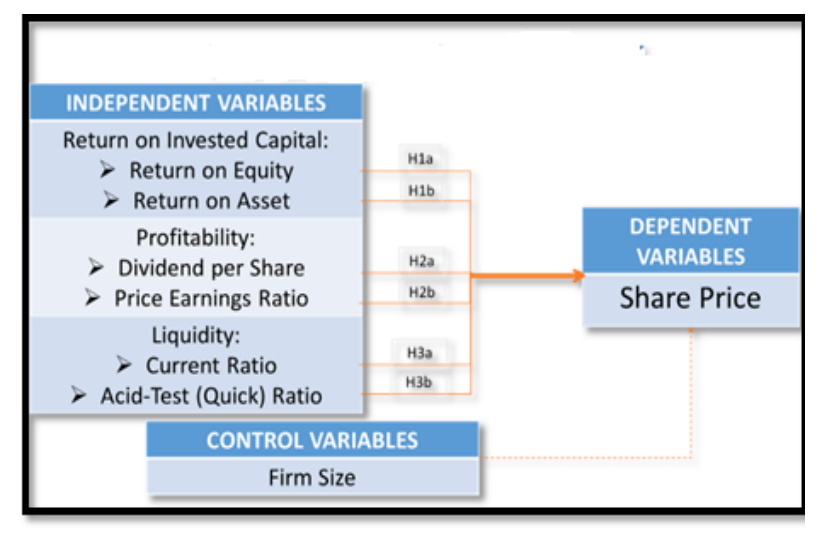

Figure 1. Research Framework of Study

\subsection{Sample Selection}

For this study, the sample firms comprise of all government-linked companies based on listing on the Government Linked Companies Transformation Programme. The years under study are from 2013 until 2017. This five-year data may provide a consistent highlight and the importance of the determinants of share prices movement. This study primarily uses secondary data, which is from the annual reports. There are two separate industries for the government-linked companies, namely, banking and non-banking. All of the financial-related data were gathered primarily from Thompson Reuters (DataStream database) and the financial statements in the company's annual report.

\subsection{Analysis of Outliers}

After inspecting extreme values on the IBM SPSS software, they were a lot of case numbers that have the lowest values or equal to 0 , and this is due to the missing values. The missing values happened because the data for Malaysia Airlines System Berhad (MAS) cannot be extracted from Thomson Reuters as well as from the annual report of MAS. Therefore, the data were removed, and the remaining data were checked for accuracy. All the data were correctly entered, and they were outliers as they were at least 1.5 interquartile ranges below the first quartile (Q1), or at least 1.5 interquartile ranges above the third quartile (Q3) [19].

\subsection{Normality Test}

Before conducting the multiple regression analysis, normality test was conducted to assess the normality of the distribution of data. This study evaluates the data normality based on the skewness and kurtosis. Normal distribution data exists if each of the skewness value is between -2.0 and +2.0 whilst the kurtosis should fall between -7.0 to +7.0 [20].

The skewness for return on asset is at 0.964 , and kurtosis is at 0.015 . Besides, the skewness and kurtosis for return on equity are at 0.928 and 2.117 , respectively. The dividend per share has a skewness of 1.310 and kurtosis of 1.580 , while the price-earnings ratio is at 4.701 (skewness) and 24.792 (kurtosis). The skewness and kurtosis for the current ratio are at 1.418 and 2.646, respectively. Acid test ratio has a skewness of 0.876 and kurtosis of 0.924 . The share price has a skewness of 0.810 and kurtosis of -0.005 . Meanwhile, the skewness and kurtosis of firm size were 2.912 and 8.258 , respectively.

In Table 1, the skewness and kurtosis for price-earnings ratio, and firm size showed a violation of normality as the values are out of the acceptable threshold. However, as the sample size is more than 30 , the violation of the normality assumption should not have any significant effect or problem [21].

\section{Results and Discussion}

Table 1. Normality Test for Variables

\begin{tabular}{|l|c|c|c|c|c|c|c|c|}
\hline & $\begin{array}{c}\text { Return on } \\
\text { Asset }\end{array}$ & $\begin{array}{c}\text { Return on } \\
\text { Equity }\end{array}$ & $\begin{array}{c}\text { Dividend Per } \\
\text { Share }\end{array}$ & $\begin{array}{c}\text { Price-Earnings } \\
\text { Ratio }\end{array}$ & Current ratio & $\begin{array}{c}\text { Acid Test } \\
\text { Ratio }\end{array}$ & $\begin{array}{c}\text { Share Price } \\
\text { Virm Size Total } \\
\text { Asset }\end{array}$ \\
\hline N $\quad$ Missing & 80 & 80 & 80 & 80 & 80 & 80 & 80 & 80 \\
Skewness & 0 & 0 & 0 & 0 & 0 & 0 & 0 & 0 \\
Std. Error of Skewness & .964 & .928 & 1.310 & 4.701 & 1.418 & .876 & .810 & 2.912 \\
Kurtosis & .269 & .269 & .269 & .269 & .269 & .269 & .269 & .269 \\
Std. Error of Kurtosis & .532 & 2.117 & 1.580 & 24.792 & 2.646 & .924 & -.005 & 8.258 \\
\end{tabular}




\subsection{Multicollinearity Test}

Multicollinearity refers to the condition that exists when independent variables are highly correlated with each other. The result of multicollinearity test for the variables were summarised in the Table 2. Multicollinearity reduces the precision of the estimate coefficients, which weakens the statistical power of the regression model. This study uses the variance inflation factor (VIF) to identify the strength of the correlation among variables. Field [19] suggested that the multicollinearity exists when the VIF value is above ten. Table 2 shows that all the VIF values are below 10. This indicates that the possibility of multicollinearity is not an issue in this study.

Table 2. Test of Multicollinearity

\begin{tabular}{|c|c|c|c|}
\hline & \multirow{2}{*}{ Model } & \multicolumn{2}{|c|}{ Collinearity Statistics } \\
\hline & & Tolerance & VIF \\
\hline \multirow[t]{7}{*}{1} & Return on Asset & .425 & 2.353 \\
\hline & Return on Equity & .555 & 1.801 \\
\hline & Dividend Per Share & .694 & 1.440 \\
\hline & Price Earnings Ratio & .882 & 1.134 \\
\hline & Current ratio & .135 & 7.390 \\
\hline & Acid Test Ratio & .129 & 7.732 \\
\hline & Firm Size Total Asset & .814 & 1.229 \\
\hline
\end{tabular}

\subsection{Descriptive Analysis}

Table 3 shows the descriptive analysis of the 17 government-linked companies (GLCs) for five years that make up a total of 80 companies from the year 2013 to year 2017. From Table 3, we can observe that the average return on asset for the sampled government-linked companies is $2.81 \%$ on the range from $0 \%$ to $9.65 \%$. The standard deviation for the return on asset is $2.33 \%$. In term of the return on equity, the average is $9.03 \%$ which indicates that majority of the sample consists of equity government-linked companies. However, there is a very large difference between minimum and maximum rate of $32.45 \%$.

For dividend per share, the rate is within the range of $0 \%$ to $0.61 \%$. The mean is $0.61 \%$. The standard deviation for dividend per share is $0.14 \%$. The mean of $0.16 \%$ indicates that on average, the sample government-linked companies are in paying dividend per share. The range of the sampled government-linked companies for price-earnings ratio variable is between $0 \%$ and $83.10 \%$, while the mean is $7.62 \%$.

The minimum for the current ratio variable is $0.16 \%$, and the maximum is $4.23 \%$. The average for the current ratio is $1.09 \%$, and the standard deviation is $0.79 \%$. The mean of $1.09 \%$ indicates that the leverage on current asset between current liabilities among sample government-linked companies. Meanwhile, the minimum for acid test ratio variable is $0.07 \%$, and the maximum is $2.93 \%$. The average for acid test ratio is $0.79 \%$, and the standard deviation is $0.62 \%$. The mean of $0.79 \%$ indicates the leverage on liquid asset between current liabilities among sampled government-linked companies.

Another continuous variable is the share price. The minimum for share price variable is RM0.90, and the maximum is RM15.26. The average for the share price is RM5.22, and the standard deviation is RM3.61. The mean of RM5.22 indicates that the share price for each share that will close on the stock market for sampled government-linked companies. Besides, the minimum for firm size variable is RM3, 449.90, and the maximum is RM1, 853,900.00. The average for firm size is RM199, 047.21, and the standard deviation is RM406, 971.08. The mean of RM199, 047.21, indicates the total asset among sample government-linked companies.

\subsection{Paired Sample T-Test}

In terms of share prices, Tables 4 and 5 show the paired sample statistics between year 2013 and 2017. In comparison, the share price in 2017 is higher than the share price in 2013. There was a statistically significant increase in share price scores from 2013 (mean $=5.15$, standard deviation $=3.96)$ to $2017($ mean $=5.84$, standard deviation $=3.68), \mathrm{t}(16)=-1.223, \mathrm{p}>.05$. The increase in mean for share prices scores was -0.6881 with a $95 \%$ confidence interval ranging from -1.88 to 0.51 , as shown in Table 5 .

Table 3. Descriptive Statistics for Variables in the years 2013 to 2017

\begin{tabular}{|c|c|c|c|c|c|c|c|c|}
\hline & $\begin{array}{c}\text { Return on } \\
\text { Asset }\end{array}$ & $\begin{array}{l}\text { Return on } \\
\text { Equity }\end{array}$ & $\begin{array}{l}\text { Dividend } \\
\text { Per Share }\end{array}$ & $\begin{array}{c}\text { Price } \\
\text { Earnings } \\
\text { Ratio }\end{array}$ & $\begin{array}{l}\text { Current } \\
\text { ratio }\end{array}$ & $\begin{array}{c}\text { Acid } \\
\text { Test } \\
\text { Ratio }\end{array}$ & $\begin{array}{l}\text { Share } \\
\text { Price }\end{array}$ & $\begin{array}{l}\text { Firm Size } \\
\text { Total Asset }\end{array}$ \\
\hline \multirow{3}{*}{$\begin{array}{r}\text { Mis } \\
\text { Mean }\end{array}$} & 80 & 80 & 80 & 80 & 80 & 80 & 80 & 80 \\
\hline & 0 & 0 & 0 & 0 & 0 & 0 & 0 & 0 \\
\hline & 2.8059 & 9.0378 & .1588 & 7.6204 & 1.0928 & .7975 & 5.2185 & 199047.21 \\
\hline Std. Deviation & 2.33442 & 6.27212 & .14424 & 12.96287 & .79777 & .62439 & 3.60875 & 406971.08 \\
\hline Minimum & .00 & .00 & .00 & .00 & .16 & .07 & .90 & 3449.90 \\
\hline Maximum & 9.65 & 32.45 & .61 & 83.10 & 4.23 & 2.93 & 15.26 & 1853900.00 \\
\hline
\end{tabular}


Table 4. Paired Sample Statistics Share Price 2013 and 2017

\begin{tabular}{|ll|c|c|c|c|}
\hline & & Mean & N & Std. Deviation & Std. Error Mean \\
\hline \multirow{2}{*}{ Pair 1 } & Share Price 2013 & 5.1531 & 16 & 3.95561 & .98890 \\
& Share Price 2017 & 5.8413 & 16 & 3.67916 & .91979 \\
\hline
\end{tabular}

Table 5. Paired Sample Test Share Price for 2013 and 2017

\begin{tabular}{|c|c|c|c|c|c|c|c|c|c|}
\hline & & \multicolumn{5}{|c|}{ Paired Differences } & \multirow{3}{*}{$\mathrm{t}$} & \multirow{3}{*}{ df } & \multirow{3}{*}{ Sig. (2-tailed) } \\
\hline & & \multirow{2}{*}{ Mean } & \multirow{2}{*}{$\begin{array}{c}\text { Std. } \\
\text { Deviation }\end{array}$} & \multirow{2}{*}{$\begin{array}{l}\text { Std. Error } \\
\text { Mean }\end{array}$} & \multicolumn{2}{|c|}{$\begin{array}{l}95 \% \text { Confidence Interval of } \\
\text { the Difference }\end{array}$} & & & \\
\hline & & & & & Lower & Upper & & & \\
\hline Pair 1 & $\begin{array}{l}\text { Share Price } 2013 \\
\text { - Share Price } 2017\end{array}$ & -.6881 & 2.25133 & .56283 & -1.88777 & .51152 & -1.223 & 15 & .240 \\
\hline
\end{tabular}

In general, the negative values of the mean indicate that the share price in 2013 was smaller than in 2017, thus showing a growth in share price score from 2013 to 2017. This increment could be because government-linked company's transformation programme is still in the early stages and might lead the companies to accelerate their strategy in line with targeted strategy review under government-linked company's transformation programme.

Table 6 shows the mean comparison between share prices from 2013 until 2017 by industry dimensions. In general, banking industries mean value is 5.41 and standard deviation is 4.00, meanwhile non-banking industry mean value is 4.90 and standard deviation is 2.87 . It shows that the mean value for the banking industry is more than the mean value for all government-linked companies shown in Table 6 (mean $=5.22$, standard deviation $=3.61$ ). Thus, the banking industry has performed better in terms of share prices compared to the non-banking industry.

Table 6. Mean Comparison for Share Price between Banking and Non-Banking Industry

\begin{tabular}{|c|c|c|c|}
\hline Industry & Mean & $\mathrm{N}$ & Std. Deviation \\
\hline Banking Industry & 5.4084 & 50 & 4.00425 \\
\hline Non-Banking Industry & 4.9020 & 30 & 2.86686 \\
\hline Total & 5.2185 & 80 & 3.60875 \\
\hline
\end{tabular}

\subsection{Correlation Matrix}

Table 8 shows the correlation matrix between variables. The positive and negative sign indicates the relationship, whether it is positively or negatively related. The results from Table 8 show that return on asset is significantly associated with the share price $(\mathrm{p}<0.05)$ and positively correlated at 0.435 . This result implies that low relationship returns on asset in government-linked companies will affect share prices. Return on equity is also significantly associated with share price $(\mathrm{p}<0.05)$. It indicates that low relationship returns on equity government-linked companies will affect share price at 0.316 . Thus, ratios for return on invested capital significantly affect the share price. On the other hand, for profitability ratio that is dividend per share and price-earnings ratio are significantly associated with share price $(\mathrm{p}<0.05)$. Dividend per share shows a high positive correlation to the share price at 0.771 . Table 8 also shows that price-earnings ratio has a low positive relationship with share price at 0.318 . Nevertheless, the other remaining independent variables (liquidity ratio), current ratio and acid test ratio were not statistically significant to the share price $(p>0.05)$. It shows that liquidity ratios do not affect the movement of share prices.

The control variable size is not statistically significant to the movement of share price $(p>0.05)$. Therefore, the size of the company does not affect the activity of share prices for government-linked companies.

\subsection{Regression Analysis}

In this section, the results and discussion are for testing the research model; as follows:

$$
\text { MSP }=
$$

$\beta 0+\beta 1(\mathrm{ROA})+\beta 2(\mathrm{ROE})+\beta 3(\mathrm{DPS})+\beta 4(\mathrm{P} . \mathrm{E})+\beta 5(\mathrm{CR})+\beta 6($

$$
\text { ATR })+\beta 7(\text { Size })+\varepsilon
$$

Where,

$$
\begin{aligned}
& \text { MSP }=\text { Movement of Share Price } \\
& \text { ROA }=\text { Return on Asset } \\
& \text { ROE }=\text { Return on Equity } \\
& \text { DPS }=\text { Dividend Per Share } \\
& \text { P.E = Price Earnings Ratio } \\
& \text { CR }=\text { Current Ratio } \\
& \text { ATR = Acid Test Ratio } \\
& 0=\text { Intercept } \\
& \beta 1=\text { Coefficient } \\
& \varepsilon=\text { Error Term of the Regression }
\end{aligned}
$$

The model above examines the relationship between financial performance and market performance. It is developed to examine all of the hypotheses in this study.

Table 7 presents the relationship between the independent variables and the dependent variable. As shown in Table 7, the adjusted $\mathrm{R}$ square for the regression model above is $66.6 \%$. This indicates that the independent variables explain $67 \%$ of the prediction of the dependent 
variables. It suggests that other contributing factors accounted for another $33 \%$ of the movements in share prices, which is not covered in this model. The regression result shows significant relationships between dividends per share, price-earnings ratio and acid test ratio with share price. Those variables are significant at $p<0.05$ level with F-value of 23.505. Thus, dividends per share, price-earnings ratio and acid test ratio are the major factors that determine the share price.

\subsubsection{Return on Invested Capital and Share Price}

Concerning the regression result, the beta coefficient for return on asset is $0.066, \mathrm{t}=0.659, \mathrm{p}=0.512$ where $\mathrm{p}>0.05$. Thus, return on asset has no significant positive relationship with the movement of share price; hence the return on asset is not a determinant of share price, thus rejecting the hypothesis 1a. Previous literature also found no significant positive relationship between return on asset and movement of the share price [e.g., 13].

Share price has a negative relationship with return on equity, suggesting that if the company has bigger return on equity, the probability of having high share price is lower. This is not consistent with the hypothesis (H1b) that predicts that a higher return on equity will increase the company's share price. The coefficient of return on equity variable is also not statistically significant at 5\% (beta coefficient $=-0.033, \mathrm{t}=-0.376$ ). Thus, there is no significant positive relationship between return on equity and share price movement, hence rejecting the hypothesis 1b. The study suggests that return on invested capital (return on asset and return on equity) is not a determinant of the share price.

\subsubsection{Profitability Ratios and Share Price}

By having good profitability ratios, it may enable the share prices to rise. The result for hypothesis 2 a (dividend per share) shown in Table 7 is positive and statistically significant $(p=0.000)$. This result demonstrates that dividend per share has a positive relationship with the movement of share prices, thus, supporting hypothesis $2 \mathrm{a}$. This finding is consistent with previous study by Almumani [17].

For the price earnings ratio, the result shows a positive relationship with share price. This suggests that that the price-earnings ratio has a significant positive relationship with the movement of share prices; hence the hypothesis $2 b$ cannot be rejected. Therefore, the study concludes that the price-earnings ratio is a determinant of the share price. The finding is supported by Almumani [17] in which there is a positive correlation between the price-earnings ratio and the market price of the share.

\subsubsection{Liquidity Ratio and Share Price}

For the liquidity ratio, which consist of current ratio, the result shows that there is negative and not statistically significant $(p=0.211)$ with the share price. This result rejects the third hypothesis, $3 \mathrm{a}$ that initially predicted that there is a significant positive relationship between the current ratio and share price. Therefore, this study rejects hypothesis $3 \mathrm{a}$.

Hypothesis $3 \mathrm{~b}$ predicts that the regression would have a positive relationship, which suggests that higher acid test ratio will increase the company's share price. The result shows a positive relationship, which indicates that acid test ratio has a significant positive relationship with the movement of share prices, thus agreeing with hypothesis $3 \mathrm{~b}$.

\subsubsection{Size and Share Price}

Turning to the control variable, size, is negative and not statistically significant at $5 \%$. As a result, size has no significant relationship with the movement of share prices. Bigger or smaller companies have no impact on share prices. The result is contradictory to many previous works of literature suggesting a significant positive relationship between size and share prices. The empirical results from Almumani [17], showed that there was a positive relationship between size and market price of shares.

Table 7. Regression Results for Share price and its Determinants

\begin{tabular}{|c|c|c|c|c|c|c|}
\hline & \multirow{2}{*}{ Model } & \multicolumn{2}{|c|}{ Unstandardized Coefficients } & $\begin{array}{l}\text { Standardized } \\
\text { Coefficients }\end{array}$ & \multirow{2}{*}{$\mathrm{t}$} & \multirow{2}{*}{ Sig. } \\
\hline & & B & Std. Error & Beta & & \\
\hline \multirow{9}{*}{1} & (Constant) & 1.371 & .635 & & 2.157 & .034 \\
\hline & Return on Asset & .102 & .154 & .066 & .659 & .512 \\
\hline & Return on Equity & -.019 & .050 & -.033 & -.376 & .708 \\
\hline & Dividend Per Share & 19.238 & 1.952 & .769 & 9.854 & .000 \\
\hline & Price Earnings Ratio & .038 & .019 & .136 & 1.962 & .045 \\
\hline & Current ratio & -1.009 & .800 & -.223 & -1.262 & .211 \\
\hline & Acid Test Ratio & 2.167 & 1.045 & .375 & 2.074 & .042 \\
\hline & Firm Size & -1.173 & .000 & -.132 & -1.835 & .071 \\
\hline & $\begin{array}{c}\text { R Square } \\
\text { Adjusted R Square } \\
\text { Std. Error of the Estimate }\end{array}$ & \multicolumn{5}{|c|}{$\begin{array}{c}0.696 \\
0.666 \\
2.08556\end{array}$} \\
\hline
\end{tabular}

a. Predictors: (Constant), Firm Size Total Asset, Price Earnings Ratio, Acid Test Ratio, Dividend Per Share, Return on Equity, Return on Asset, Current ratio 
Table 8. Pearson Correlations Coefficients between Variables (Share Price and its Determinants)

\begin{tabular}{|c|c|c|c|c|c|c|c|c|c|}
\hline & & $\begin{array}{c}\text { Return on } \\
\text { Asset }\end{array}$ & $\begin{array}{l}\text { Return on } \\
\text { Equity }\end{array}$ & $\begin{array}{c}\text { Dividend Per } \\
\text { Share }\end{array}$ & $\begin{array}{c}\text { Price } \\
\text { Earnings } \\
\text { Ratio }\end{array}$ & $\begin{array}{l}\text { Current } \\
\text { ratio }\end{array}$ & $\begin{array}{l}\text { Acid Test } \\
\text { Ratio }\end{array}$ & Share Price & $\begin{array}{l}\text { Firm Size } \\
\text { Total Asset }\end{array}$ \\
\hline \multirow{2}{*}{ Return on Asset } & $\begin{array}{c}\text { Pearson } \\
\text { Correlation }\end{array}$ & \multirow[t]{2}{*}{1} & .414 & .318 & .209 & .429 & .480 & .435 & -.192 \\
\hline & Sig. (2-tailed) & & .000 & .004 & .063 & .000 & .000 & .000 & .087 \\
\hline \multirow{2}{*}{ Return on Equity } & $\begin{array}{c}\text { Pearson } \\
\text { Correlation }\end{array}$ & & \multirow[t]{2}{*}{1} & .407 & .084 & -.234 & -.214 & .316 & -.194 \\
\hline & Sig. (2-tailed) & & & .000 & .461 & .037 & .057 & .004 & .084 \\
\hline \multirow{2}{*}{$\begin{array}{c}\text { Dividend Per } \\
\text { Share }\end{array}$} & $\begin{array}{c}\text { Pearson } \\
\text { Correlation }\end{array}$ & & & \multirow[t]{2}{*}{1} & .184 & -.055 & -.048 & .771 & .185 \\
\hline & Sig. (2-tailed) & & & & .103 & .629 & .676 & .000 & .101 \\
\hline \multirow{2}{*}{$\begin{array}{c}\text { Price Earnings } \\
\text { Ratio }\end{array}$} & $\begin{array}{c}\text { Pearson } \\
\text { Correlation } \\
\end{array}$ & & & & \multirow[t]{2}{*}{1} & -.066 & .020 & .318 & -.056 \\
\hline & Sig. (2-tailed) & & & & & .562 & .863 & .004 & .621 \\
\hline \multirow[t]{2}{*}{ Current ratio } & $\begin{array}{c}\text { Pearson } \\
\text { Correlation }\end{array}$ & & & & & \multirow[t]{2}{*}{1} & .925 & .095 & .097 \\
\hline & Sig. (2-tailed) & & & & & & .000 & .400 & .391 \\
\hline \multirow[t]{2}{*}{ Acid Test Ratio } & $\begin{array}{c}\text { Pearson } \\
\text { Correlation } \\
\end{array}$ & & & & & & \multirow[t]{2}{*}{1} & .165 & .061 \\
\hline & Sig. (2-tailed) & & & & & & & .143 & .591 \\
\hline \multirow[t]{2}{*}{ Share Price } & $\begin{array}{c}\text { Pearson } \\
\text { Correlation } \\
\end{array}$ & & & & & & & \multirow[t]{2}{*}{1} & -.003 \\
\hline & Sig. (2-tailed) & & & & & & & & .979 \\
\hline \multirow{2}{*}{$\begin{array}{c}\text { Firm Size Total } \\
\text { Asset }\end{array}$} & $\begin{array}{c}\text { Pearson } \\
\text { Correlation } \\
\end{array}$ & & & & & & & & \multirow[t]{2}{*}{1} \\
\hline & Sig. (2-tailed) & & & & & & & & \\
\hline
\end{tabular}

\section{Conclusion}

This study contributes to the determinants of share prices literature, especially in developing nations, by examining the sample of government-linked companies (GLCs). Specifically, the time frame of this study is between 2013 and 2017. In respect of the differences between bank and non-bank sectors of GLCs, using mean comparison, it shows that banking sectors are performing better in terms of having higher share prices as compared to its counterpart. The correlations also revealed return on asset, return on equity, dividend per share, and price-earnings ratio are significant variables affecting the share prices of government-linked companies. Thus, government-linked companies can focus on strengthening their financial information in those aspects to increase share price or market performance. The multiple regressions analyses provide evidence that dividend per share, price-earnings ratio and acid test ratio had a significant positive relationship with the movement of share prices. Therefore, $\mathrm{H} 2 \mathrm{a}, \mathrm{H} 2 \mathrm{~b}$, and $\mathrm{H} 3 \mathrm{~b}$ were accepted while H1a, H1b and H3a were rejected. Profitability (dividend per share and price-earnings ratio) variables have positive relationships with share prices; therefore, it is accepted. Also, this study could not reject $\mathrm{H} 3 \mathrm{~b}$ because the acid test ratio (liquidity) had a significant positive relationship with the share price. Lastly, the control variable size had no meaningful relationship with the movement of share price with $p>0.05$. The findings divulge that dividends per share, price-earnings ratio and acid test ratio affect share prices, significantly. Thus, dividends per share, price-earnings ratio and acid test ratio are the significant factors that determine the movement of share prices for government-linked companies in Malaysia. It shows that the government-linked company's transformation programme might help the companies to increase their performance in terms of the share price.

The findings of this study are subject to certain limitations and thus provide motivations for future research. First, there is a limitation on this study in relation to the time frame about the data. Since the period selected only for five years between 2013 and 2017, it is suggested a prospect for an avenue to a longer durations to perceive a better relationship. Second, this study used 17 government-linked companies as the sample size and then the sample has to be reduced to 16 government-linked companies after the analysis of the outliers. Since this study is focusing on GLCs as samples, it does not make any comparisons with the non-GLCs. Therefore, further research on this topic should be conducted by comparing the performance of GLCs with its counterpart.

\section{REFERENCES}

[1] Udding, M. B. (2009). Determinants of the market price of stock: A study on bank leasing and Industrial Services, and Food Company Shares. Journal of Modern Accounting and Auditing, 5(7), pp. 1-7. 
[2] Gatua, F.K. (2013). Analysis of share price determinants at Nairobi securities exchange. Dissertation submitted for Master of Business Administration Degree. The University of Nairobi.

[3] Irfan, CM and Nishat, M. (2002). Key Fundamental Factors and Long-run Price Changes in an Emerging Market - A Case Study of Karachi Stock Exchange (KSE). The Pakistan Development Review, 41:4 Part 2 (Winter 2002), pp. 517-533.

[4] Isa, M. and Lee. S (2016). The Performance of Government-Linked Companies in Malaysia. Capital Markets Review, 24 (2), pp. 1-13.

[5] Aziz, A. (2019). 'GLCs underperformance in the spotlight'. The Edge Financial Daily, October 31, 2019. Available at https://www.theedgemarkets.com/article/glcs-underperform ance-spotlight. (Accessed on July 12, 2020).

[6] Lau, Y.K. and CQ. Tong (2008). Are Malaysian government-linked companies (GLCs) creating value? International Applied Economics and Management Letters, 1(1), pp. 9-12.

[7] Putrajaya Committee on GLC High Performance (2015), GLC Transformation Programme Graduation Report.

[8] Razak, N. H. Ab, Ahmad, R. and Joher, H.A. (2011). Does Government Linked Companies (GLCs) perform better than non-GLCs? Evidence from Malaysian listed companies, Journal of Applied Finance \& Banking, 1(1), pp. 213-240.

[9] Wang, Z., and Wang, N. (2012). Knowledge sharing, innovation, and firm performance. Expert Systems with Applications, 39(10), pp. 8899-8908.

[10] Mahbob, TSDS (2018). 'GLCs have critical roles'. New Straits Times, January 30 2018. Available at https://www.nst.com.my/opinion/columnists/2018/01/3301 73/glcs-have-critical-roles

[11] Bernama (2019). 'PM: GLCs, GLICs must focus on helping fuel nation's growth'. New Straits Times, October 302019. Available at https://www.nst.com.my/news/nation/2019/10/ 534285/pm-glcs-glics-must-focus-helping-fuel-nations-gro wth. (Accessed on July 12 2020).

[12] Fischel, D.R. (1978). Efficient Capital Market Theory, the Market for Corporate Control, and the Regulation of Cash Tender Offers. 57 Texas Law Review, 1, pp. 1-46.

[13] Naveed and Ramzan (2013). A View about the determinants of change in share prices: A case from Karachi Stock Exchange (banking sector). Interdisciplinary Journal of Contemporary Research in Business, 4 (12) (April 2013), pp. 41-57.

[14] Uwuigbe, U., Olusegun, O. and Goodswill, A. (2012). An Assessment of the Determinants of Share Price in Nigeria: A Study of Selected Listed Firms. Acta Universitatis Danubius. OEconomica 8, no. 6 (January 10, 2012).

[15] Enow, S.T. \& Brijlal, P. (2016). Determinants of Share Prices: The Case of Listed Firms on the Johannesburg Stock Exchange. Journal of Accounting and Management. 6 (1), pp. 85-92.

[16] Malhotra, N. and Tandon, K. (2013). Determinants of stock prices: Empirical evidence from NSE 100 Companies. International Journal of Research in Management \& Technology, 3(3), pp. 89-95.

[17] Almumani, MA (2014). Determinants of equity share prices of the listed banks in Amman stock exchange: Quantitative approach. International Journal of Business and Social Science, 5(1), pp. 91-104.

[18] Alves. H., Canadas, N. and Rodrigues, A.M. (2015). Determinants of Share Price and Share Liquidity: An Analysis Using a SEM Model. Procedia Economics and Finance, 25, pp. $318-331$.

[19] Field, A. (2013). Discovering Statistics using IBM SPSS Statistics (4th ed.): SAGE Publications Ltd.

[20] Hair, J. F., Black, W. C., Babin, B. J., \& Anderson, R. E. (2010). Multivariate Data Analysis (7th ed.). Prentice Hall, Upper Saddle River, New Jersey. (Accessed on July 12 2020).

[21] Pallant, J. (2011). SPSS survival manual. A step by step guide to data analysis using SPSS program (4th ed). 